JOEAI (Journal of Education and Instruction)

Volume 1, Nomor 2, Desember 2018

e-ISSN : 2614-8617

p-ISSN : 2620-7346

DOI: https://doi.org/10.31539/joeai.v1i2.490

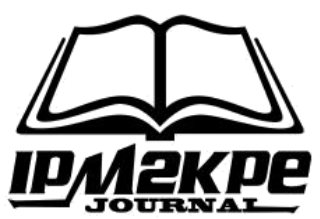

\title{
PENGEMBANGAN SOAL MATEMATIKA MODEL PISA UNTUK MENGUKUR KEMAMPUAN PENALARAN MATEMATIKA SISWA
}

\author{
Elya Rosalina ${ }^{1}$, As Elly $\mathbf{S}^{2}$ \\ STKIP PGRI Lubuklinggau ${ }^{1,2}$ \\ elyarosalina25@gmail.com ${ }^{1}$
}

\begin{abstract}
ABSTRAK
Tujuan penelitian, mengembangkan soal matematika model PISA untuk mengukur kemampuan penalaran matematika siswa SMP Negeri di Kota Lubuklinggau. Penelitian ini merupakan penelitian pengembangan atau development research tipe formative research. Penelitian ini dilakukan melalui dua tahap yaitu pleminary dan tahap formatif evaluation yang meliputi self evalution, expert reviews dan one-to-one (low resitence to revision) dan small group serta field test (hight resistence in revison). Teknik analisis data yang digunakan dalam penelitian ini analisis data deskriptif. Hasil penelitian, berdasarkan proses pengembangan yang diperoleh, prototype perangkat soal yang dikembangkan memiliki efek potensial, hal ini terlihat dari hasil tes yang telah diberikan dengan nilai rata-rata keseluruhan 61,09 yang menunjukan bahwa kemampuan penalaran matematika siswa termasuk dalam kategori baik dengan skala kategori baik itu adalah 61 - 80. Simpulan, pengembangan soal matematika model PISA mampu mengukur kemampuan penalaran matematika siswa.
\end{abstract}

Kata Kunci: Soal, PISA, Kemampuan, dan Penalaran

\section{ABSTRACT}

The purpose of the study was to develop a mathematical problem of the PISA model to measure the mathematical reasoning ability of students of the Lubuklinggau City Middle School. This research is a development research or development research type formative research. This research was conducted through two stages, namely pleminary and formative evaluation stages which included self evaluation, expert reviews and one-to-one (low resistance to revision) and small groups and field tests (hight resistance in revison). The data analysis technique used in this study was descriptive data analysis. The results of the research, based on the development process obtained, the prototype of the question set developed has a potential effect, this can be seen from the results of tests that have been given with an overall average score of 61.09 which shows that students' mathematical reasoning abilities are included in both categories with a scale of categories well it is 61 - 80. Conclusions, the development of PISA mathematical problems is able to measure students' mathematical reasoning abilities.

Keywords: Questions, PISA, Ability, and Reasoning 


\section{PENDAHULUAN}

Matematika merupakan salah satu mata pelajaran disekolah yang mendapatkan perhatian terbesar baik dari kalangan pendidik, orang tua maupun anak. Kebanyakan orang tua beranggapan bahwa matematika adalah pengetahuan terpenting yang harus dikuasai oleh anak, dan menjadi tolak ukur dari seluruh mata pelajaran lain yang diajarkan. Matematika memiliki ciri khas dibanding ilmu pengetahuan lain yaitu karena sifatnya yang abstrak, sehingga pengetahuan matematika tidak dapat dipindahkan utuh begitu saja dari pikiran guru kepikiran siswa dalam menerima suatu materi pelajaran.

Pada hakekatnya matematika menuntut siswa untuk terus belajar, berusaha secara mandiri, serta menjadi suatu keharusan yang tidak bisa ditawar lagi untuk penataan nalar sehingga dalam menyelesaikan soal-soal matematika tidak bergantung pada orang lain (Brodie, 2009). Siswa diharapkan memiliki kemampuan penalaran dan dalam penerapannya siswa dalam menyelesaikan persoalan matematika siswa dapat berpikir dan bernalar, karena pada dasarnya setiap penyelesaian soal matematika bentuk apapun memerlukan kemampuan penalaran. Sumarmo (2005) mengemukakan bahwa pembelajaran matematika hendaknya mengutamakan daya matematika siswa yang meliputi kemampuan menggali, menyusun konjektur dan menalar secara logik, menyelesaikan soal yang tidak rutin, dan pemecahan masalah.

Depdiknas (2006) mengemukakan bahwa materi matematika dan penalaran matematika adalah dua hal yang tidak dapat dipisahkan, yaitu materi matematika dipahami melalui penalaran dan penalaran dipahami dan dilatihkan melalui belajar materi matematika. Menurut Sumarmo (2005) salah satu visi pembelajaran matematika yaitu mengarahkan pada pemahaman konsep matematika yang diperlukan untuk menyelesaikan masalah matematika dan masalah ilmu pengetahuan lainnya serta memberikan kemampuan penalaran matematis siswa. Hal tersebut sejalan dengan yang dirumuskan oleh National Council of Teachers of Mathematics (2000), yaitu: kemampuan komunikasi matematis (mathematical communication); kemampuan penalaran matematis (mathematical reasoning); kemampuan pemecahan masalah (mathematical problem solving); kemampuan koneksi matematis (mathematical connections). Merujuk uraian diatas, kemampuan penalaran termuat pada standar menurut NCTM, artinya kemampuan penalaran ini penting dikembangkan dan dimiliki oleh siswa.

Kemampuan penalaran (reasoning) merupakan salah dari komponen proses standar dalam Principles and Standards for School Mathematics selain dari kemampuan pemecahan masalah, representasi, komunikasi dan koneksi. Penalaran matematika (mathematical reasoning) yaitu suatu kegiatan, proses atau aktivitas berpikir yang dilakukan untuk menarik kesimpulan yang logis atau untuk membuat pernyataan baru yang mendasar pada beberapa pernyataan yang diketahui benar ataupun yang dianggap benar (Fitriyah, 2013). Penalaran 
matematika juga bisa digunakan untuk mengetahui dalam mengerjakan soal matematika, sehingga siswa dengan mudah bisa memecahkan permasalahannya. Hasil studi NAEP menunjukkan bahwa siswa masih mengalami kesulitan ketika dihadapkan pada permasalahan yang menuntut kemampuan penalaran maupun kemamampuan pemecahan masalah (Suherman, et al, 2003).

PISA (Programme for International Students Assessment) merupakan studi internasional tentang literasi membaca, matematika, dan sains siswa sekolah berusia 15 tahun. Studi ini dikoordinasikan oleh OECD (Organisation for Economic Cooperation and Development) yang berkedudukan di Paris, Prancis. PISA merupakan studi yang diselenggarakan setiap tiga tahun sekali, yaitu pada tahun 2000, 2003, 2006, 2009, dan seterusnya (OCED, 2009).

Berdasarkan hasil survey PISA menunjukkan bahwa kemampuan matematika siswa Indonesia masih rendah, baik pada dimensi konten maupun dimensi kognitif. Penilaian dimensi konten pada domain: bilangan, aljabar, geometri, data dan peluang, sedangkan penilaian dimensi kognitif pada domain: 1) pengetahuan, mencakup fakta-fakta, konsep dan prosedur yang harus diketahui siswa; 2) penerapan, yang berfokus pada kemampuan siswa menerapkan pengetahuan dan pemahaman konsep untuk menyelesaikan masalah atau menjawab pertanyaan; 3) penalaran, yang berfokus pada penyelesaian masalah non rutin, konteks yang kompleks dan melakukan langkah penyelesaian masalah yang banyak (Balitbang, 2011).

Pernyataan diatas sesuai dengan survey yang pernah dilakukan oleh JICAIMSTEP pada tahun 1999 di Bandung, bahwa dalam bermatematika yang dipandang sulit oleh siswa maupun guru matematika SMP adalah justifikasi atau pembuktian, pemecahan masalah yang memerlukan penalaran matematika, menemukan generalisasi atau konjektur, dan menemukan hubungan antara faktafakta yang diberikan menurut Suryadi (dalam Wahidin, 2013).

Soal-soal matematika dalam PISA lebih banyak mengukur tingkat kemampuan penalaran, pemecahan masalah, dan argumentasi daripada soal-soal yang mengukur kemampuan teknis yang berkaitan dengan ingatan serta perhitungan yang biasa dilakukan. Dalam soal PISA terdapat delapan ciri kemampuan kognitif matematika yaitu mathematical thinking and reasoning, mathematical argumentation, modelling, problem posing and solving, representation, symbols and formalism, communication dan penggunaan aids and tools. Semua kemampuan kognitif dalam soal PISA tersebut berkaitan dengan tujuan pembelajaran matematika yang terdapat pada kurikulum.Masalah yang sering dihadapi oleh guru yaitu kurang tersedianya soal-soal yang didesain khusus yang sesuai dengan potensi siswa dan karakter siswa sehingga diasumsikan bahwa potensi siswa dalam menggunakan penalaran dalam menjawab soal belum berkembang secara maksimal.Hal tersebut bisa mengakibatkan rendahnya hasil kemampuan penalaran matematika siswa (Ariyadi, 2012). 
Menurut Utami, et al (2014) penalaran merupakan suatu cara berpikir untuk menarik kesimpulan, baik kesimpulan yang bersifat umum yang ditarik dari hal-hal yang bersifat khusus maupun hal-hal yang bersifat umum dapat menjadi kesimpulan yang yang bersifat khusus. Sedangkan menurut Sumarmo (Ario, 2016) penalaran matematis adalah suatu kemampuan yang muncul dalam bentuk menarik kesimpilan yang logis; mengunakan penjelasan dengan model, fakta, sifat-sifat dan hubungan; memperkirakan jawaban dan proses solusi, menggunakan pola dan hubungan; menganalisis situasi matematik; menarik analogi dan generalisasi; menyusun dan mengkaji konjektur; memberi contoh penyangkal; mengikuti aturan inferensi; memeriksa validitas argumen; menyusun argumen yang valid; memyusun pembuktian langsung, tak langsung dan mengunakan induksi matematika.

Upaya yang diperlukan dalam mengoptimalkan sikap positif siswa yaitu guru perlu memberikan sosialisai tentang apa serta bagaimana karakteristik dan framework tentang soal-soal PISA dengan cara pengembangannya dan mengadaptasikan soal-soal model PISA untuk mengimplementasikan dalam proses pembelajaran.Berdasarkan uraian tersebut, maka yang perlu dikembangkan dalam soal-soal matematika yaitu soal yang berbasis kemampuan penalaran matematika siswa dengan model PISA sebagai wujud apresiasi dalam perbaikan evaluasi pembelajaran, adapun tujuan penelitian ini, mengembangkan soal matematika model PISA untuk mengukur kemampuan penalaran matematika siswa SMP Negeri Kota Lubuklinggau.

\section{METODE PENELITIAN}

Penelitian ini merupakan penelitian pengembangan atau development research tipe formative research (Tessmer,1999; Zukardi, 2002). Penelitian pengembangan ini dilaksanakan untuk menghasilkan soal-soal matematika model PISA untuk mengukur kemampuan penalaran matematika siswa Sekolah Menengah Pertama yang valid dan praktis. Penelitian ini dilakukan melalui dua tahap yaitu pleminary dantahapformatif evaluation yang meliputiself evalution, expert reviews danone-to-one (low resitence to revision) dan small group sertafield test (hight resistence in revison).

Teknik analisis data yang digunakan dalam penelitian ini analisis data deskriptif digunakan untuk menganalis data validasi ahli dengan cara merevisi berdasarkan wawancara atau catatan validator, serta pemeriksaan dokumen soal model PISA oleh validator atau guru. Hasil dari analisis digunakan untuk merevisi soal-soal yang telah dibuat oleh peneliti (Arikunto, 2010).

\section{HASIL DAN PEMBAHASAN}

\section{Hasil Pengembangan}

Pelaksanaan penelitian yang telah diuraikan pada bab sebelumnya melalui dua tahap yaitu pleminary dan tahap formatif evaluation yang meliputi self 
evalution, expert reviews dan one-to-one (low resitence to revision) dan small group serta field test (hight resistence in revison).

\section{Tahap Pleminary}

Penelitian ini dilakukan di tiga Sekolah Menengah Pertama Kota Lubuklinggau yakni ini di SMP Negeri 4 Lubuklinggau, SMP Negeri 14 Lubuklinggau, dan SMP PGRI 3 Lubuklinggau untuk mengetahui kemampuan penalaran matematika siswa SMP Kota Lubuklinggau.Sebagai subjek penelitian dilakukan di kelas siswa IX SMP Kota Lubuklinggau.

\section{TahapFormatif Evaluation}

\section{Self Evaluation}

\section{Analisis}

Analisis kurikulum tingkat Sekolah Menengah Pertama pada tahap ini mengacu pada satuan pendidikan SMP Negeri 4 Lubuklinggau, SMP Negeri 14 Lubuklinggau, dan SMP PGRI 3 Lubuklinggau.

\section{Desain}

Dalam penelitia ini, pendesainan yang dilakukan penelitii yaitu mengenai kisi-kisi dan soal-soal model PISA untuk mengetahui kemampuan penalaran matematika Sekolah Menengah Pertama di tiga sekolah yaitu SMP Negeri 4 Lubuklinggau, SMP Negeri 14 Lubuklinggau, dan SMP PGRI 3 Lubuklinggau.Pada pendesainan soal yang dibuat oleh peneliti meliputi tiga karakteristik yakni, konten, konstruk, dan bahasa.

\section{Prototyping}

\section{Expert reviews}

Pada tahap uji coba pakar ini disebut uji validitas.Produk yang didesain dilihat, dinilai, dan dievaluasi berdasarkan konten, konstruk dan bahasa.Saransaran dari validator digunakan untuk merevisi desain soal-soal yang dibuat oleh peneliti.

\section{One-to-one}

Pada pelaksanaan penelitian di tahap ini soal yang di ujicobakan kepada anak (one-to-one) bernama Sandri Prayuda, Mela Agnesah, Putri Apriliyanti yang merupakan siswa SMP Negeri 4 Lubuklinggau yang mempunyai kemampuan tinggi, sedang, dan rendah untuk mengerjakan soal matematika model PISA berjumlah 20 soal. Soal matematika yang diberikan kepada siswa tersebut dipandu oleh peneliti. Kemudian peneliti melakukan interaksi serta komunikasi kepada siswa tersebut melalui kegiatan wawancara untuk melihat kesulitan apa saja yang dirasakan oleh siswa saat pengerjaan soal matematika model PISA sehingga peneliti dapat mengetahui soal tersebut perlu diperbaiki atau tidak. Pada saat melakukan ujicoba soal pada tahap ini siswa hanya mampu mengerjakan 10 soal saja dikarenakan soal yang diberikan terlalu sulit dan mereka pun belum terbiasa mengerjakan soal matematika model PISA. Sesuai dengan saran dan komentar 
para ahli pada expert review dan one-to-one yang telah dilaksanakan oleh peneliti maka pada tahap selanjutnya soal yang digunakan hanya 10 soal saja pada prototipe II soal matematika model PISA yang digunakan yaitu pada konten ruang dan bentuk (space and shape),yang akan diujicobakan pada tahap small group

\section{Small Group}

Soal matematika model PISA pada prototipe kedua diujicobakan pada small group kepada enam orang siswa SMP Negeri 4 Lubuklinggau yaitu Rezky Utama Putra, M. Dendi Agung A.P, Rizki Kurniawan, Encik Dzaky Khoiry, Sinta Rahmayani, Putra Apriliansyah yang mempunyai kemampuan tinggi, sedang, dan rendah. Pada pelaksanaan tahap ini peneliti mengujicobakan soal matematika model PISA dengan mengamati kegiatan siswa dalam pengerjaan soal secara berkelompok.Selain itu juga peneliti bertanya kepada siswa mengenai kesulitankesulitan yang mereka hadapi dalam pengerjaan soal matematika model PISA tersebut, guna untuk mengetahui kendala dan apakah soal perlu diperbaiki atau tidak oleh peneliti untuk tahap selanjutnya.

Setelah dilaksanakan ujicoba, hasil yang diperoleh pada saat ujicoba pada tahap one-to-one dengan ujicoba pada tahap small group dalam pengerjaan soal matematika model PISA siswa tidak terlalu banyak mengalami kesulitan seperti pada proses one-to-one yang menyatakan soal yang diberikan terlalu banyak sehingga mereka sulit memahami maksud dari soal, dan dalam pengerjaan dan menjawab soal mereka beranggapan soalnya terlalu sulit.

\section{Field Test}

Pengembangan soal matematika model PISA pada prototipe III ini untuk mengukur kemampuan penalaran matematika siswa sekolah menengah pertama Kota Lubuklinggau di ujicobakan ketiga sekolah di Kota Lubuklinggau, yaitu SMP Negeri 4 Lubuklinggau berjumlah 30 siswa, SMP Negeri 14 Lubuklinggau berjumlah 28 siswa, dan SMP PGRI 3 Lubuklinggau 31 siswa. Subjek penelitiannya yakni siswa SMP kelas IX guna melihat efek potensial soal penalaran matematika model PISAterhadap kemampuan penalaran matematika siswa (Suryadi,2007).

Proses pengembangan yang sudah dilalui yang terdiri dari tiga tahap, yaitu self evaluation, prototyping (expert reviews dan one to one, small group) dan field test serta revisi pada masing-masing tahap maka diperoleh perangkat soal matematika model PISA untuk mengukur kemampuan penalaran matematika dikategorikan valid dan praktis. Soal tersebut dinyatakan valid setelah melalui proses validasi dari beberapa validator yang memberikan kontribusi berupa saran dan komentar terhadap perbaikan soal baik dari segi konten, kontruk dan bahasa. Berdasarkan hasil analisispenilaian kevaitan soal oleh para ahli yang merupakan ahli konten, ahli konstruk dan ahli bahasa diperoleh rata-rata skor sebesar 3,25 yang dalam kategori vallid dan layak dipakai dengan beberapa revisi yang harus dilakukan (Dalyana, 2004). 
Hasil revisi berdasarkan komentar/saran dan lembar jawaban siswa pada one-to-one dan small group evaluation menunjukkan soal yang dikembangkan praktis. Soal tersebut dikategorikan praktis tergambar dari hasil pengamatan pada uji coba small group, dimana semua siswa dapat menggunakan perangkat soal dengan baik. Soal yang dikembangkan sesuai dengan alur pikiran siswa, mudah dibaca, dan tidak menimbulkan penafsiran yang beragam (Saputri, 2017).

Field test proses pelakasanaan ujicoba pada setiap sekolah dilakasanakan selama satu hari selama 2 jam pelajaran yakni pada tanggal 2 Agustus 2018 dilaksanakan di SMP Negeri 4 Lubuklinggau, pada tanggal 4 Agustus 2018 di SMP Negeri 14 Lubuklinggau, dan pada tanggal 6 Agustus 2018 di SMP PGRI 3 Lubuklinggau. Pada saat penelitian berlangsung peneliti berkomunikasi dan berinteraksi kepada siswa untuk mengetahui apa saja kendala yang dihadapi siswa saat pengerjaan soal matematika model PISA ini. Untuk memperoleh data dalam pelaksanaan penelitian ini yaitu dengan cara memberikan ujicoba soal matematika model PISA kepada siswa yang mana soal tersebut telah divalidasi terlebih dahulu oleh para ahli. Field test ini bertujuan untuk mengetahui efek potensial soal penalaran matematis model PISA terhadap kemampuan penalaran matematika siswa. Soal-soal yang diberikan pada field test ini merupakan soal-soal yang telah valid dan praktis. Soal yang diberikan pada siswa terdiri dari 10 soal. Berdasarkan hasil analisis rata-rata nilai kemampuan penalaran siswa diperoleh sebesar 61,09 dalam kategori baik.

\section{SIMPULAN}

Prototype perangkat soal yang dikembangkan dikategorikan valid dan praktis. Perangkat soal yang dikembangkan terdiri dari 10 soal model PISA pada konten Space and shape. Berdasarkan proses pengembangan diperoleh bahwa Prototype perangkat soal yang dikembangkan memiliki efek potensial, hal ini terlihat dari hasil tes yang telah diberikan dengan nilai rata-rata keseluruhan 61,09 yang menujukan bahwa kemampuan penalaran matematika siswa termasuk dalam kategori baik dengan skala kategori baik itu adalah $61-80$.

\section{DAFTAR PUSTAKA}

Arikunto. (2010). Prosedur Penelitian Suatu Pendekatan Praktik. Jakarta: PT Rineka Cipta.

Ariyadi, W. (2012).Pendidikan Matematika Realistik Suatu Alternatif Pendekatan Pembelajaran Matematika. Yogyakarta: Graha Ilmu.

Badan Penelitian dan Pengembangan (Balitbang). (2011). Laporan Hasil TIMSS 2007.Kementrian Pendidikan dan Kebudayaan.

Brodie, K. (2009). Teaching Mathematical Reasoning Secondary School Classroom. The Open University.

Dalyana. (2004). Pengembangan Perangkat Pembelajaran Matematika Realistik pada Pokok Bahasan Perbandingan di Kelas VIII SMP. Surabaya: UNESA. 
Depdiknas. (2006). Kurikulum 2006 Mata Pelajaran Matematika SMP/MTs. Jakarta: Dirjen Manajemen Dikdasmen Departemen Pendidikan Nasional.

Fitriyah, N. (2013). Pengembangan Pembelajaran Matematika dengan Metode Eksplorasi dan Elaborasi untuk Melatihkan Kemampuan Komunikasi Matematis Siswa pada Sub Pokok Bahasan Fungsi. Surabaya: UIN Sunan Ampel Surabaya.

Ketut, S. (2002). Pengantar Pelaksanaan Program Bimbingan dan Konseling di Sekolah. Jakarta: Rineka Cipta

National Council of Teachers of Mathematics. (2000). Principle and Standarts of School Mathematics. Reston: NCTM.

OECD. (2009). PISA Assesment Framework.http://www.oecd.org. (17 September 2016).

Saputri. (2017). Kemampuan Penalaran Matematis Siswa Menggunakan Pendekatan Metaphorical Thinking Pada Materi Perbandingan Kelas Viii Di Smpn 1 Indralaya Utara.Jurnal Elemen. 3(1), 15-24.

Suherman, E. (2003). Strategi Pembelajaran Matematika Kontemporer. Bandung: Depdiknas-JICA-UPI.

Sumarmo, U. (2005). "Pembelajaran Matematika untuk Mendukung Pelaksanaan Kurikulum Tahun 2002 Sekolah Menengah”. Makalah disajikan pada seminar Pendidikan Matematika di FPMIPA Universitas Negeri Gorontalo tanggal 7 Agustus 2005.

Suryadi. (2007). Ilmu dan Aplikasi Pendidikan Bagian Tiga.Bandung: JICA-UPI.

Utami. (2014). Kemampuan Penalaran Matematis Siswa Kelas XI IPA SMAN 2 Painan Melalui Penerapan Pembelajaran Think Pair Square. Jurnal Pendidikan Matematika 3(1)

Wahidin. (2013). Pola dan Kekeliruan Matematika, Tinjauan terhadap Kemampuan Penalaran.Prosiding Seminar Nasional Matematika dan Pendidikan Matematika Vol. 1 